\title{
Studies on the Enzymology of Purified Preparations of Brush Border from Rabbit Kidney
}

\author{
By S. G. GEORGE and A. J. KENNY \\ Department of Biochemistry, University of Leeds, 9 Hyde Terrace, Leeds LS2 9LS, U.K.
}

(Received 16 November 1972)

\begin{abstract}
1. A method for the preparation of brush border from rabbit kidneys is described. Contamination by other organelles was checked by electron microscopy and by the assay of marker enzymes and was low. 2 . Seven enzymes, all hydrolases, were substantially enriched in the brush-border preparation and are considered to be primarily located in this structure. They are: alkaline phosphatase, maltase, trehalase, aminopeptidase A, aminopeptidase $\mathbf{M}, \gamma$-glutamyl transpeptidase and a neutral peptidase assayed by its ability to hydrolyse [ $\left.{ }^{125} \mathrm{I}\right]$ iodoinsulin B chain. 3. Adenosine triphosphatases were also present in the preparation, but showed lower enrichments. 4. Alkaline phosphatase was the most active phosphatase present in the preparation. The weak hydrolysis of AMP may well have been due to this enzyme rather than a specific 5'-nucleotidase. 5 . The two disaccharidases in brush border were distinguished by the relative heat-stability of trehalase compared with that of maltase. 6 . The individuality of the four peptidases was established by several means. The neutral peptidase and aminopeptidase $M$, both of which can attack insulin B chain, differed not only in response to inhibitors and activators but also in the inhibitory effect of a guinea-pig antiserum raised to rabbit aminopeptidase $M$. This antiserum inhibited both the purified and the brush-border activities of aminopeptidase $M$. The neutral peptidase and $\gamma$-glutamyl transpeptidase were unaffected but aminopeptidase $\mathrm{A}$ was weakly inhibited. The characteristic responses to $\mathrm{Ca}^{2+}$ and serine with borate served to distinguish aminopeptidase $A$ and $\gamma$-glutamyl transpeptidase from other peptidases. 7. No dipeptidases, tripeptidases or carboxypeptidases were identified as brush-border enzymes. 8. Incubation of brush border with papain released almost all the aminopeptidase $M$ activity but only about half the activities of maltase, $\gamma$-glutamyl transpeptidase and aminopeptidase A. No release of alkaline phosphatase, trehalase or the neutral peptidase was observed.
\end{abstract}

The proximal tubule of the kidney is the major site along the nephron for the reabsorption of nutrients from the glomerular filtrate. Specific transport processes are located there for glucose (Loeschke \& Baumann, 1969) and amino acids (Bergeron \& Morel, 1969). Proteins are also taken up in this region of the nephron by a process of pinocytosis with subsequent digestion of the contents of each vacuole by lysosomal enzymes (Strauss, 1957; Miller \& Palade, 1964). The morphological feature of the proximal tubule cell that is characteristic of its reabsorptive function is the brush border. This structure is a specialization of the apical pole of the cell into a large number of microvilli, with a consequent increase in the luminal surface area.

One way of furthering our understanding of the function of the kidney brush border would be to isolate the microvilli and to study their enzymology and ultrastructural organization. The results of such a study might well have a more general relevance about the plasma membrane of mammalian cells, since the microvilli of the brush border are only a specialized version of this membrane. The usual techniques for homogenizing tissues cause extensive disruption of the brush border, with the result that free microvilli sediment with the microsomal pellet. Further fractionation of this pellet can effect some enrichment of microvilli, but the similarity in density of microvilli to membranous vesicles derived from the endoplasmic reticulum precludes the possibility of obtaining homogeneous preparations (Kenny et al., 1969). More recently a number of workers have reported methods for the preparation of brush-border fragments from the kidney of rat (Thuneberg \& Rostgaard, 1968; Kinne \& Kinne-Saffran, 1969; Wilfong \& Neville, 1970) and rabbit (Berger \& Sacktor, 1970; Quirk \& Robinson, 1972). In each method the preliminary disruption of the kidney cortex was performed by relatively gentle means to minimize the shearing of microvilli from the rest of the membrane. These brush-border fragments then sediment at low speeds and may be separated from other cell organelles by rate-zonal centrifugation in suitable density gradients. 
The enzymes so far identified in purified preparations of kidney brush border include: alkaline phosphatase (orthophosphoric monoester phosphohydrolase, EC 3.1.3.1); 5'-nucleotidase (5'-ribonucleotide phosphohydrolase, EC 3.1.3.5); aminopeptidase M (aminoacyl-oligopeptide hydrolase, EC 3.4.1.2); maltase ( $\alpha$-D-glucoside glucohydrolase, EC 3.2.1.20); trehalase $\left(\alpha \alpha^{\prime}\right.$-glucoside 1-glucohydrolase, EC 3.2.1.28); ATPases* (ATP phosphohydrolase, EC 3.6.1.3) and $\gamma$-glutamyl transpeptidase (glutamineD-glutamyl glutamyltransferase, EC 2.3.2.1). In this paper we report on the enzymology of rabbit kidney brush border prepared by a method differing in some respects from those hitherto described. Independently of Quirk \& Robinson (1972) we have employed the B XIV zonal rotor in one of the preparative steps, but in other respects our procedure differs markedly from their scheme. We have also extended the study of the brush-border enzymes. In particular we have evidence that the brush border contains four distinct peptidases. One of these, referred to as the 'neutral peptidase', hydrolyses $\left[{ }^{125} I\right]$ iodoinsulin B chain, and is distinct from aminopeptidase $M$. In addition, aminopeptidase $\mathbf{A}$, an enzyme specific for $\alpha$-glutamic acid 2-naphthylamide and $\alpha$-aspartic acid 2-naphthylamide (Glenner et al., 1962) is also located in the brush border. $\gamma$-Glutamyl transpeptidase is enriched in our preparation to a greater degree than that reported by Glossmann \& Neville (1972). Evidence for the separate identities of these peptidases and, indeed, the other hydrolases of the brush border has been obtained by a detailed study of the properties of the enzymes.

\section{Methods}

\section{Preparation of purified brush border}

Young adult New Zealand White rabbits weighing $2-3 \mathrm{~kg}$ were used. Animals were killed by cervical dislocation and the kidneys were rapidly removed and chilled in ice-cold $11 \%(\mathrm{w} / \mathrm{v})$ sucrose. All operations were carried out at $4^{\circ} \mathrm{C}$. The concentration of sucrose solutions is given as \%(w/v). About $50 \mathrm{~g}$ of cortex, obtained from eight kidneys, was disrupted in a tissue press (Climpex Ltd., London N.W.7, U.K.) in which the tissue was forced through a wire gauze, $20 \mathrm{mesh} /$ linear $\mathrm{cm}$, apertures $0.25 \mathrm{~mm}$. The minced cortex was suspended in $500 \mathrm{ml}$ of $11 \%$ sucrose (homogenate). The homogenate was centrifuged for $10 \mathrm{~min}$ at $1250 \mathrm{~g}$ (International Centrifuge, HR-1, rotor $856,2000 \mathrm{rev} . / \mathrm{min})$. The pinkish top layer of the sediment was resuspended with the supernatant by gentle swirling of the tube contents. The remaining pellets were combined and resuspended in $180 \mathrm{ml}$ of $11 \%$ sucrose by one stroke of a hand-operated glass-Teflon homogenizer (bore $25 \mathrm{~mm}$; clearance

\footnotetext{
* Abbreviation: ATPase, adenosine triphosphatase.
}

$0.19 \mathrm{~mm}$ ). Both suspensions were then re-centrifuged as described above. The pink top layers of the pellets were resuspended with the supernatants, and the suspension was centrifuged for $10 \mathrm{~min}$ at $3250 \mathrm{~g}$ (same rotor, $4000 \mathrm{rev} . / \mathrm{min}$ ). After aspiration of the supernatants, the pink top layer of each pellet was washed out with $5 \mathrm{ml}$ of $11 \%$ sucrose. The combined washes were made up to $300 \mathrm{ml}$ and suspended by two strokes of the hand-operated homogenizer. The suspension was centrifuged for $12 \mathrm{~min}$ at $3250 \mathrm{~g}$ (International Centrifuge, rotor $860,24 \times 12 \mathrm{ml}$; $4000 \mathrm{rev}$. $/ \mathrm{min}$ ). The pink top layer was removed and resuspended in $90 \mathrm{ml}$ of $11 \%$ sucrose as in the previous stage. The suspension was then centrifuged for $6 \mathrm{~min}$ at $22000 \mathrm{~g}$ (Beckman-Spinco Centrifuge, model L2 65B; rotor SW 27; $17 \mathrm{ml}$ tubes; $13000 \mathrm{rev} . / \mathrm{min}$, without braking). The pink top layer was firmly pelleted but could be removed by a jet of sucrose medium, containing $11 \%$ sucrose, $10 \mathrm{mM}-\mathrm{MgCl}_{2}$ and $10 \mathrm{~mm}$-Tris- $\mathrm{HCl}$ buffer, $\mathrm{pH} 7.6\left(4^{\circ} \mathrm{C}\right)$, from a syringe. The suspension was made up to $75 \mathrm{ml}$ in the same medium and could be stored at $-10^{\circ} \mathrm{C}$ overnight.

Subsequent purification of this crude fraction involved zonal centrifugation. A B XIV Ti zonal rotor running in a MSE Superspeed 65 centrifuge was used. Loading was carried out at $3000 \mathrm{rev} . / \mathrm{min}$ and sucrose solutions (containing $\mathrm{MgCl}_{\mathbf{2}}$ and Tris- $\mathrm{HCl}$ buffer as described above) were introduced via the perimeter in the following order: $60 \mathrm{ml}$ of $36 \% ; 150 \mathrm{ml}$ of $43 \%$; $140 \mathrm{ml}$ of $51 \%$, and sufficient $60 \%$ sucrose to fill the rotor. The sample $(75 \mathrm{ml}$ vol.) was introduced via the centre feed and followed by $120 \mathrm{ml}$ of a solution containing only $10 \mathrm{~mm}-\mathrm{MgCl}_{2}$ and $10 \mathrm{~mm}-\mathrm{Tris}-\mathrm{HCl}$ buffer, $\mathrm{pH}$ 7.6. The rotor was then capped and spun at $37500 \mathrm{rev} . / \mathrm{min}$ for $60 \mathrm{~min}$, and then allowed to decelerate to $3000 \mathrm{rev} . / \mathrm{min}$ without braking. The contents were displaced by $60 \%$ sucrose solution introduced via the perimeter, and $10 \mathrm{ml}$ fractions were collected. The fractions containing purified brush border were found at the $36 \% / 43 \%$-sucrose interface. The fractions were monitored by assaying aminopeptidase $M$ activity; those of maximum specific activity were pooled, diluted by addition of $2 \mathrm{vol}$. of water, and the brush-border fragments sedimented by centrifugation for $30 \mathrm{~min}$ at $15000 \mathrm{~g}$ (International Centrifuge, rotor $856 ; 18000 \mathrm{rev} . / \mathrm{min})$.

\section{Chemical determinations}

Protein was measured by the procedure of Lowry et al. (1951). The phenol reagent was standardized with bovine serum albumin by the method of Oyama \& Eagle (1956).

\section{Enzyme assays}

Aminopeptidase A. This was assayed fluorimetrically. The incubation mixture $(2 \mathrm{ml})$ contained $0.2 \mathrm{mM}$ - 
L- $\alpha$-glutamic acid 2-naphthylamide as substrate and $0.1 \mathrm{M}$-Tris- $\mathrm{HCl}$ buffer, $\mathrm{pH} 7.0\left(37^{\circ} \mathrm{C}\right)$.

Aminopeptidase $M$. This was assayed similarly with either $0.2 \mathrm{~mm}$-L-leucine 2-naphthylamide, $0.2 \mathrm{mM}-\mathrm{L}$-arginine 2-naphthylamide or $0.2 \mathrm{mM}-\mathrm{L}-$ alanine 2-naphthylamide as substrate.

$\gamma$-Glutamyl transpeptidase. This was assayed with $0.2 \mathrm{mM}-\mathrm{L}-\gamma$-glutamic acid 2-naphthylamide as substrate and $3 \mathrm{mM}$-glycylglycine as acceptor in $0.1 \mathrm{M}$ Tris- $\mathrm{HCl}$ buffer, $\mathrm{pH} 8.5\left(37^{\circ} \mathrm{C}\right)$.

Cathepsin $C$ (EC 3.4.4.9). This was assayed with $0.05 \mathrm{~mm}$-histidylserine 2-naphthylamide (Fox Chemical Co., Los Angeles, Calif., U.S.A.) as substrate, in $10 \mathrm{~mm}$-sodium cacodylate- $10 \mathrm{~mm}$-cysteamine hydrochloride, $\mathrm{pH}$ 6.0. In each of the above enzyme assays the initial rate of release of 2-naphthylamine was measured in an Aminco-Bowman SP.125 spectrophotofluorimeter equipped with a thermoconstant cell compartment and chart recorder.

'Neutral peptidase' activity. This was measured at pH7.0 with [ $\left.{ }^{125} \mathrm{I}\right]$ iodoinsulin $B$ chain as substrate. The radioactive substrate, prepared from $6 \times$ recrystallized insulin by the method of Crestfield et al. (1963), was iodinated with ${ }^{125} \mathrm{ICl}(60 \mu \mathrm{Ci} / \mu \mathrm{mol})$ at $\mathrm{pH} 2.8$ by the method of Glover et al. (1967). The product contained $2 \mathrm{~g}$-atoms of $\mathrm{I} / \mathrm{mol}$ of peptide. The incubation mixture for the enzymic assay contained $2.8 \mathrm{nmol}$ of iodoinsulin B chain, and $60 \mu \mathrm{mol}$ of Tris $-\mathrm{HCl}$ buffer in a volume of $0.5 \mathrm{ml}$. After incubation for $15 \mathrm{~min}$ at $37^{\circ} \mathrm{C}$ the reaction was stopped by the addition of $0.5 \mathrm{ml}$ of $2 \%(\mathrm{w} / \mathrm{v})$ casein and $1.0 \mathrm{ml}$ of $25 \%(w / v)$ trichloroacetic acid. After centrifugation the radioactivity in the supernatant was assayed in a $\gamma$-scintillation counter. The radioactivity (c.p.m.) in the supernatant was corrected for non-precipitable radioactivity in the controls (enzyme omitted).

'Acid peptidase'. This activity was assayed by the same procedure but in $0.12 \mathrm{M}$-glycine- $\mathrm{HCl}$ buffer, pH3.5.

Cathepsin D (EC 3.4.4.23). This was assayed in the same manner, but with $\left.{ }^{125} I\right]$ iodohaemoglobin as substrate.

The hydrolysis of simple peptides was measured by the method described by Binkley et al. (1968).

Non-specific alkaline phosphatase. This was assayed with $p$-nitrophenyl phosphate as substrate by the method of Bessey et al. (1946).

Acid phosphatase (EC 3.1.3.2). This was assayed by the method of Gianetto \& de Duve (1955).

Glucose 6-phosphatase (EC 3.1.3.9). This activity was measured by the method of de Duve et al. (1955).

ATPase. This activity was measured in the presence of $\mathrm{Na}^{+}, \mathrm{K}^{+}$and $\mathrm{Mg}^{2+}$ by the method of Jorgensen \& Skou (1969). $\mathrm{Mg}^{2+}$-ATPase was the activity in the presence of $1 \mathrm{~mm}$-ouabain.

$5^{\prime}$-Nucleotidase. This was assayed by the method of Michell \& Hawthorne (1965).
Maltase and trehalase. These were assayed by the method of Dahlqvist (1964).

$\beta$-Glucuronidase (EC 3.2.1.31). This was assayed at pH5.2, after the fractions had been frozen and thawed three times, by the method of Gianetto \& de Duve (1955).

Rhodanese (EC 2.8.1.1). This was measured by the method described by Bowen et al. (1965).

Arylesterase (EC 3.1.1.2). This activity was assayed fluorimetrically. The incubation mixtures $(2 \mathrm{ml} \mathrm{vol}$.) contained $0.34 \mathrm{~mm}$-substrate and $30 \mathrm{~mm}$-sodium phosphate buffer, pH7.0. With 1-naphthyl acetate as substrate the release of 1-naphthol was followed (excitation $306 \mathrm{~nm}$, emission $460 \mathrm{~nm}$ ), and with 2-naphthyl acetate as substrate the release of 2-naphthol was followed (excitation $306 \mathrm{~nm}$, emission $350 \mathrm{~nm}$ ). Enzyme concentrations were adjusted to give less than $2 \%$ hydrolysis of the substrate in $4 \mathrm{~min}$, to avoid the need for correction for alteration of quenching, as there is a concentration-dependent quenching of the product fluorescence by the substrate.

Enzyme units. Units are expressed as $\mu \mathrm{mol}$ of substrate converted $/ \mathrm{min}$ at $37^{\circ} \mathrm{C}$. Specific activity is defined as units/mg of protein.

\section{Treatment of brush border with papain}

The incubation mixture (16ml vol.; pH6.8) contained $10.2 \mathrm{mg}$ of brush-border protein, $0.3 \mathrm{M}$-sucrose, $12.5 \mathrm{~mm}-\mathrm{KCl}, 75 \mathrm{~mm}$-Tris- $\mathrm{HCl}$ buffer, $0.1 \mathrm{~mm}$-dithiothreitol, $0.1 \mathrm{~mm}$-cysteine, $0.9 \mathrm{mg}$ of papain [ $2 \times$ recrystallized; Sigma (London) Chemical Co., Kingston-upon-Thames, U.K.; the stock was previously diluted to give a solution containing $0.3 \mathrm{mg}$ of papain $/ \mathrm{ml}$ in $5 \mathrm{~mm}$-dithiothreitol-5mM-cysteine, pH6.2]. During incubation at $37^{\circ} \mathrm{C}$, samples $(4 \mathrm{ml}$ vol.) were withdrawn at intervals, cooled to $0^{\circ} \mathrm{C}$ and centrifuged at $105000 \mathrm{~g}, 4^{\circ} \mathrm{C}$, for $60 \mathrm{~min}$. A control mixture, otherwise similarly constituted, contained $12.5 \mathrm{~mm}$-iodoacetate to inactivate the papain.

\section{Purification of aminopeptidase $M$}

Cortical tissue from ten rabbit kidneys $(60 \mathrm{~g})$ was homogenized in $600 \mathrm{ml}$ of $0.33 \mathrm{M}$-sucrose by using an Ultra-Turrax homogenizer (Janke und Kunkel K.G., Staufen, Germany) for $1 \mathrm{~min}$. After successive removal of pellets sedimenting at $2000 \mathrm{~g}$ for $4 \mathrm{~min}$ and $8000 \mathrm{~g}$ for $7.5 \mathrm{~min}$, a microsomal fraction was sedimented at $75000 \mathrm{~g}$ for $120 \mathrm{~min}$. This pellet was resuspended in $100 \mathrm{ml}$ of a medium similar to that used for the papain treatment of the brush border, described above. After incubation for $60 \mathrm{~min}$ at $37^{\circ} \mathrm{C}$, the suspension was centrifuged $(75000 \mathrm{~g}, 120 \mathrm{~min})$ and the supernatant was treated with solid recrystallized $\left(\mathrm{NH}_{4}\right)_{2} \mathrm{SO}_{4}$. The fraction precipitated between 40 and $80 \%$ saturation was suspended in $10 \mathrm{ml}$ of 
water and dialysed overnight against 10 litres of $0.05 \mathrm{M}$-Tris- $\mathrm{HCl}$ buffer, $\mathrm{pH} 8.2$. The non-diffusible material appeared cloudy and an inactive precipitate was removed by centrifugation at $17000 \mathrm{~g}$ for $15 \mathrm{~min}$. The clear supernatant was further purified by chromatography on DEAE-cellulose (Whatman DE 32, microgranular) at $4^{\circ} \mathrm{C}$. The column $(6 \mathrm{~cm} \times 1.6 \mathrm{~cm}$ diam.) was equilibrated with $0.05 \mathrm{M}-\mathrm{Tris}-\mathrm{HCl}$ buffer, pH 8.2, and after loading, the column was eluted by a linear gradient generated from a two-flask apparatus. The initial flask contained $150 \mathrm{ml}$ of the equilibration buffer and the second flask contained $150 \mathrm{ml}$ of $0.4 \mathrm{M}-\mathrm{NaCl}-33 \mathrm{~mm}-\mathrm{KH}_{2} \mathrm{PO}_{4}, \mathrm{pH} 7.0$. The flow rate was approx. $30 \mathrm{ml} / \mathrm{h}$. The fractions containing most of the aminopeptidase $M$ activity were pooled, concentrated by precipitation with $\left(\mathrm{NH}_{4}\right)_{2} \mathrm{SO}_{4}$, and then dialysed overnight. The nondiffusible material $(2 \mathrm{ml}$ vol.) was finally purified by column electrophoresis as described by Fullarton \& Kenny (1970) by using 1\% (w/v) Ampholine, pH 6-8 (LKB-Produkter A.B., Stockholm, Sweden) as carrier electrolyte.

The purified enzyme appeared homogeneous by disc electrophoresis in polyacrylamide gels and on ultracentrifugation (Kenny et al., 1969). The specific activity of the preparation was in the range 65-90 units/mg of protein. This represented a 500-700-fold purification from the cortex homogenate.

\section{Aminopeptidase $M$ antiserum}

Three guinea pigs each received $1 \mathrm{mg}$ of purified aminopeptidase M emulsified with Freund's complete adjuvant by subcutaneous injection. A second injection in incomplete adjuvant was given 17 days after the first and the animals were bled after a further 21 days. The globulin fraction was precipiated with $50 \%$-satd. $\left(\mathrm{NH}_{4}\right)_{2} \mathrm{SO}_{4}$ and dialysed overnight against $0.1 \mathrm{M}$-sodium phosphate buffer, $\mathrm{pH}$ 7.5. The specificity of the antiserum was investigated by immunodiffusion and immunoelectrophoresis in agar gels, as described by Sargent (1969). A single precipitin line was observed when the antiserum was diffused against purified aminopeptidase $M$, or against the supernatant fraction obtained after papain treatment of brush borders.

\section{Electron microscopy}

Samples for electron microscopy were fixed with $2.5 \%(\mathrm{v} / \mathrm{v})$ glutaraldehyde in $0.1 \mathrm{M}$-sodium phosphate buffer (pH 7.5) containing $0.5 \% \mathrm{NaCl}$, washed with the same buffer, post-fixed with buffered $2 \%(w / v)$ osmium tetroxide (pH7.5), dehydrated through graded alcohols and propylene oxide, and embedded in Epon. Ultrathin sections, stained with lead citrate, were examined in a Philips EM 300 electron microscope operating at $80 \mathrm{kV}$.

\section{Results \\ Homogenization conditions}

The use of a tissue press, by which tissue may be forced through steel meshes of various sizes, permitted a systematic study of the relationship of the extent of tissue disintegration to the yield of brush-border fragments.

Other workers (Thuneberg \& Rostgaard, 1968; Kinne \& Kinne-Saffran, 1969) have stressed the need for gentle homogenization if intact fragments of brush border rather than free microvilli are to be obtained in significant amounts. In Table 1 the results of a variety of treatments on rat kidneys are compared. Aminopeptidase $M$ was assayed as a marker enzyme for microvilli in three fractions. By using light- and electron-microscopy, fraction S1 was found to contain unbroken cells, including short lengths of tubules, as well as nuclei. Fraction S2 contained brush-border fragments and other membranous components. The supernatant fraction (SN) after sedimentation of fraction $\mathbf{S} 2$ contained mitochondria, lysosomes and microsomal elements, including free microvilli.

The yield of aminopeptidase $\mathbf{M}$ in fraction $\mathbf{S 2}$ increased steadily from $4.5 \%$ to $22 \%$ as finer meshes were used in the tissue press. This was associated with a corresponding fall in the percentage of this activity in fraction S1. However, the finer meshes also caused further disruption of the brush border, so that over $50 \%$ of the activity appeared in the supernatant fraction. The other treatments were inferior to the tissue press in providing a good yield in fraction S2. The Dounce homogenizer appeared to be best of these other procedures, but yielded no more than $12 \%$ in the brush-border fraction. Even minimal treatment with a Potter-Elvehjem homogenizer caused $73 \%$ of the activity to appear in the supernatant. Grinding of frozen kidneys or fine chopping of fresh kidneys yielded only $7 \%$ of the activity in the brush-border fraction.

The most successful results were obtained by forced passage through a wire mesh, 20 meshes/cm, apertures of $0.25 \mathrm{~mm}$, supporting a $56 \mu \mathrm{m}$ nylon mesh. Unfortunately, the extra pressure needed to force tissue through the nylon mesh was liable to damage the screw thread on the tissue press. Consequently the nylon mesh was omitted in the routine preparation of brush border, at the cost of some loss in yield. Since nearly half the activity remained in fraction S1, it seemed worthwhile to attempt a further disruption of the fragments of tubules in this fraction. Treatment in a Dounce homogenizer released about $10 \%$ of the activity from fraction S1, of which $2 \%$ sedimented in 
(a)

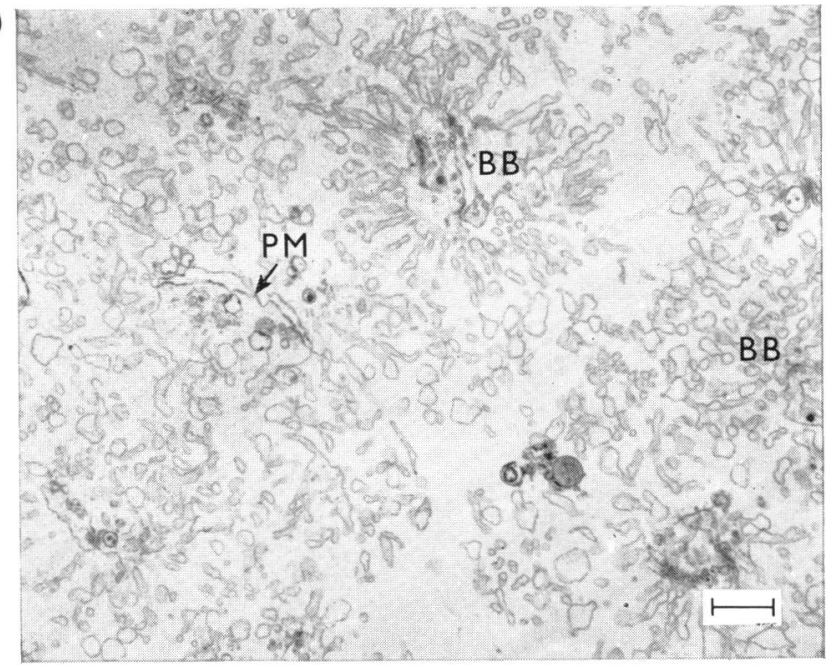

(b)

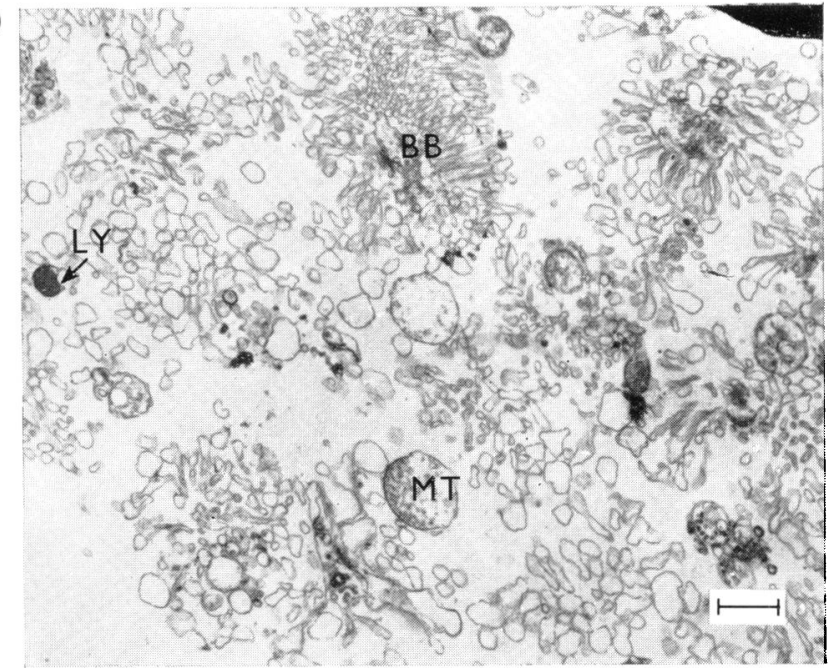

EXPLANATION OF PLATE I

Electron micrographs of pelleted fractions of kidney cortex prepared in a B XIV zonal rotor

The fractions are from the experiment shown in Fig. 1. For details see the Methods section. The scale line represents $1 \mu \mathrm{m}$. (a) Pellet prepared from the pooled fractions 12,13 and 14. It is rich in brush borders (BB), to some of which portions of lateral plasma membrane (PM) are attached (magnification $\times 6000)$ ). $(b)$ Pellet from fraction 18. It contains many brush borders (BB), but is contaminated with lysosomes (LY) and mitochondria (MT) (magnification $\times 6000$ ). 
(a)

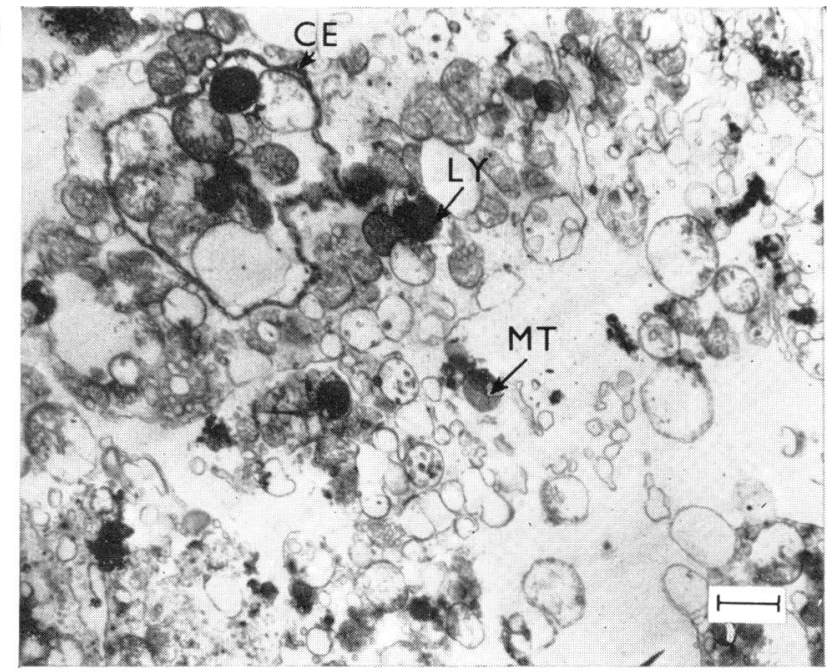

(b)

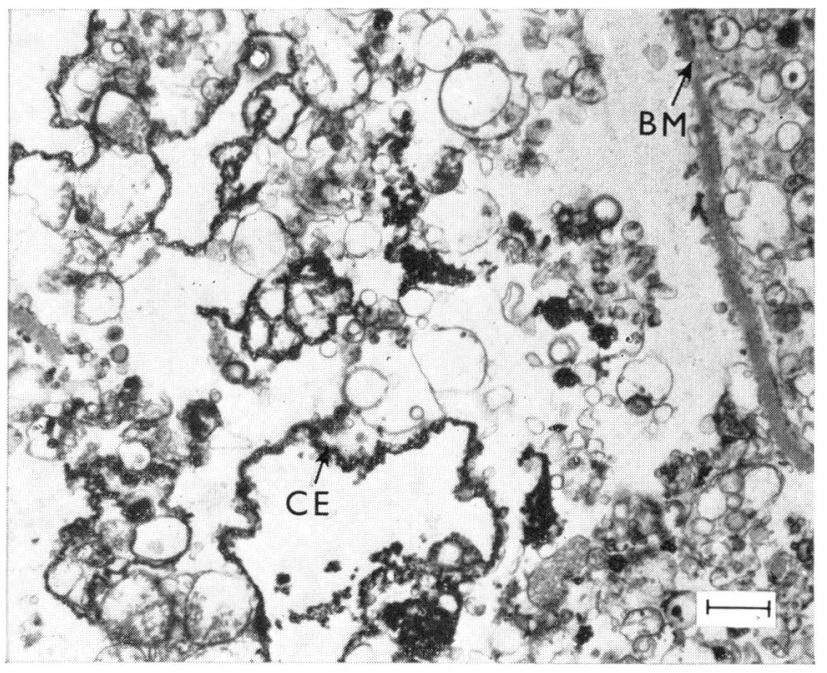

EXPLANATION OF PLATE 2

Electron micrographs of pelleted fractions of kidney cortex prepared in a B XIV zonal rotor

The fractions are from the experiment shown in Fig. 1. For details see the Methods section. Scale line represents $1 \mu \mathrm{m}$. (a) Pellet from fraction 21. It is rich in lysosomes (LY) and mitochondria (MT) and contains some fragments of capillary endothelium (CE) (magnification $\times 6000$ ). (b) Pellet from fraction 26 . It contains many large fragments of capillary endothelium (CE) and basement membrane (BM) (magnification $\times 6000)$. 
Table 1. Effect of homogenization conditions on the distribution of aminopeptidase $M$ in subcellular fractions

Whole rat kidneys were used. Results are the means of two experiments. Fraction S1 was sedimented at $300 \mathrm{~g}$ for $5 \mathrm{~min}$, and fraction $\mathrm{S} 2$ at $3000 \mathrm{~g}$ for $10 \mathrm{~min}$. Fraction $\mathrm{SN}$ is the supernatant after removal of fraction $\mathrm{S} 2$.

\begin{tabular}{|c|c|c|c|}
\hline \multirow[b]{2}{*}{ Method of homogenization } & \multicolumn{3}{|c|}{$\begin{array}{c}\text { Enzyme activity/fraction } \\
(\%)\end{array}$} \\
\hline & S1 & S2 & SN \\
\hline Tissue press: metal plate, 33 holes $/ \mathrm{cm}^{2}, 2.7 \mathrm{~mm}$ diameter & 82 & 4.5 & 13.5 \\
\hline Tissue press: metal plate, 33 holes $/ \mathrm{cm}^{2}, 2.0 \mathrm{~mm}$ diameter & & 7.5 & \\
\hline Tissue press: wire gauze, 12 meshes $/ \mathrm{cm}$, apertures $0.6 \mathrm{~mm}$ & 70.5 & 8.5 & 21 \\
\hline Tissue press: wire gauze, 16 meshes $/ \mathrm{cm}$, apertures $0.4 \mathrm{~mm}$ & 55.5 & 12 & 32.5 \\
\hline Tissue press: wire gauze, 20 meshes $/ \mathrm{cm}$, apertures $0.25 \mathrm{~mm}$ & 47 & 14.5 & 48.5 \\
\hline Tissue press: wire gauze, 20 meshes $/ \mathrm{cm}$, and $106 \mu \mathrm{m}$-mesh nylon & 16.5 & 17.5 & 66 \\
\hline Tissue press: wire gauze, 20 meshes $/ \mathrm{cm}$, and $56 \mu \mathrm{m}$-mesh nylon & 22 & 22 & 56 \\
\hline Tissue press: wire gauze, 20 meshes $/ \mathrm{cm}$, and $35 \mu \mathrm{m}$-mesh nylon & 21 & 16 & 63 \\
\hline Kidneys frozen in liquid $\mathrm{N}_{2}$, ground in mortar for $10 \mathrm{~s}$ & 65 & 7 & 28 \\
\hline Kidneys chopped with 12 razor blades spaced $0.3 \mathrm{~mm}$ apart & 44 & 7 & 49 \\
\hline Dounce homogenizer: pestle clearance $0.2-0.5 \mathrm{~mm}, 5$ strokes & 61.5 & 12 & 23.5 \\
\hline Dounce homogenizer: pestle clearance $0.2-0.5 \mathrm{~mm}, 10$ strokes & 56 & 7.5 & 36.5 \\
\hline Potter-Elvehjem glass-Tefion homogenizer: clearance $0.2 \mathrm{~mm}$, & 18 & 9 & 73 \\
\hline
\end{tabular}

fraction $\mathrm{S} 2$ and $8 \%$ appeared in the supernatant fraction.

Preparation of brush borders and distribution of enzymic activities after centrifugation in a $B X I V$ rotor

The disruption of kidney cortex by the tissue press improved the yield of brush border obtained by either the method of Thuneberg \& Rostgaard (1968) or the modification described by Berger \& Sacktor (1970). However, in the final stages of both these procedures, a significant amount of brush-border material has to be sacrificed in order to prevent gross contamination of the preparations by lysosomes. For this reason, in the present study we have used the preliminary differential-centrifugation stages as described by Kinne \& Kinne-Saffran (1969) to prepare a crude brush-border fraction. This fraction was then purified by centrifugation through a discontinuous sucrose density gradient in a B XIV zonal rotor.

Fig. 1 shows the results of a typical preparation. Protein peaks were observed in five zones of the gradient, the maximum concentrations occurring in fractions $7,13,18,21$ and 26 . Peak 7 represented protein remaining in the sample zone which had not migrated into the gradient. Peak 13 was held up at the $36 \% / 43 \%$-sucrose interface. Peak 18 was a minor component that had entered the $43 \%$-sucrose zone. Peak 21, which was not fully resolved from this minor component, was held up at the $43 \% / 51 \%$ sucrose interface. Peak 26 had migrated as far as the $60 \%$-sucrose 'cushion.'
Seven of the enzymes monitored in this preparation showed similar distribution patterns, with most of the activity appearing in peak 13 and a minor component in peak 18. This group of enzymes comprised aminopeptidase $A$, aminopeptidase $M$, alkaline phosphatase, neutral peptidase, maltase, trehalase and $\gamma$-glutamyl transpeptidase. The remaining enzymes were differently distributed. ATPase activity was concentrated in peaks 13,21 and 26 , whereas rhodanese and cathepsin $\mathrm{C}$ were principally found in peaks 7, 21 and 26.

Electron micrographs of pellets obtained from the peak fractions are shown in Plates 1 and 2. No pellet was obtained from fraction 7 , which appeared therefore to be composed of soluble protein and/or fragments of low density. It included some material derived from lysosomes and mitochondria, since both rhodanese and cathepsin $\mathrm{C}$ activities were present in this fraction. The pellet obtained by combining fractions 12,13 and 14 (Plate $1 a$ ) was very rich in brush border. In six areas, each measuring $270 \mu \mathrm{m}^{2}$, 60 brush-border clumps were counted, but only two lysosomes, three mitochondria and five membrane fragments not associated with brush border. Brushborder clumps also predominated in fraction 18 (Plate 1b), but greater contamination from lysosomes and mitochondria was observed. This fraction represents a portion of the main zone of brush border that had penetrated the interface between the $36 \%$ and $43 \%$-sucrose zones and was merging with the peak located at fraction 21. This latter fraction (Plate $2 a$ ) contained many lysosomes, mitochondria, 

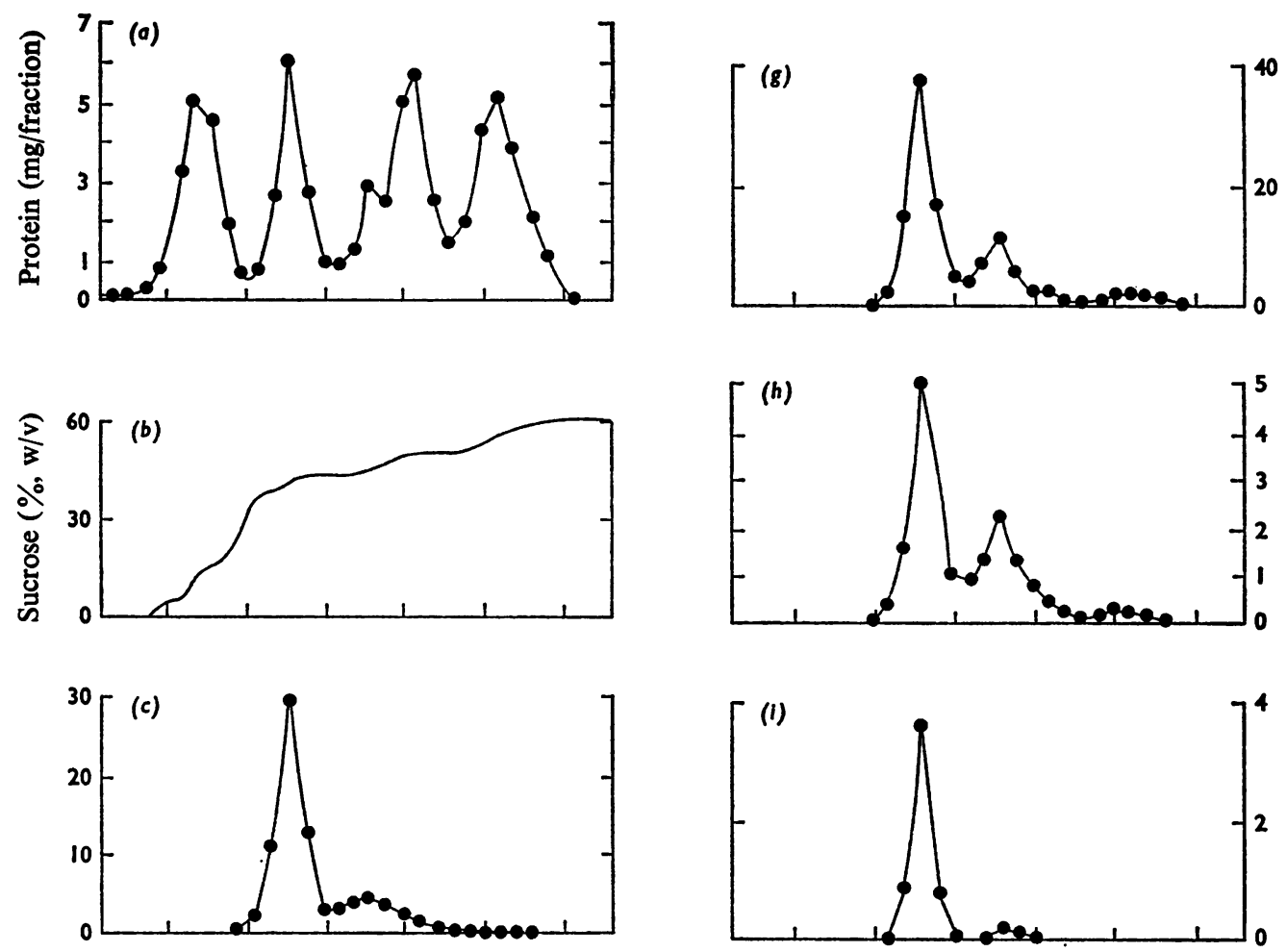

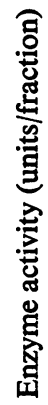
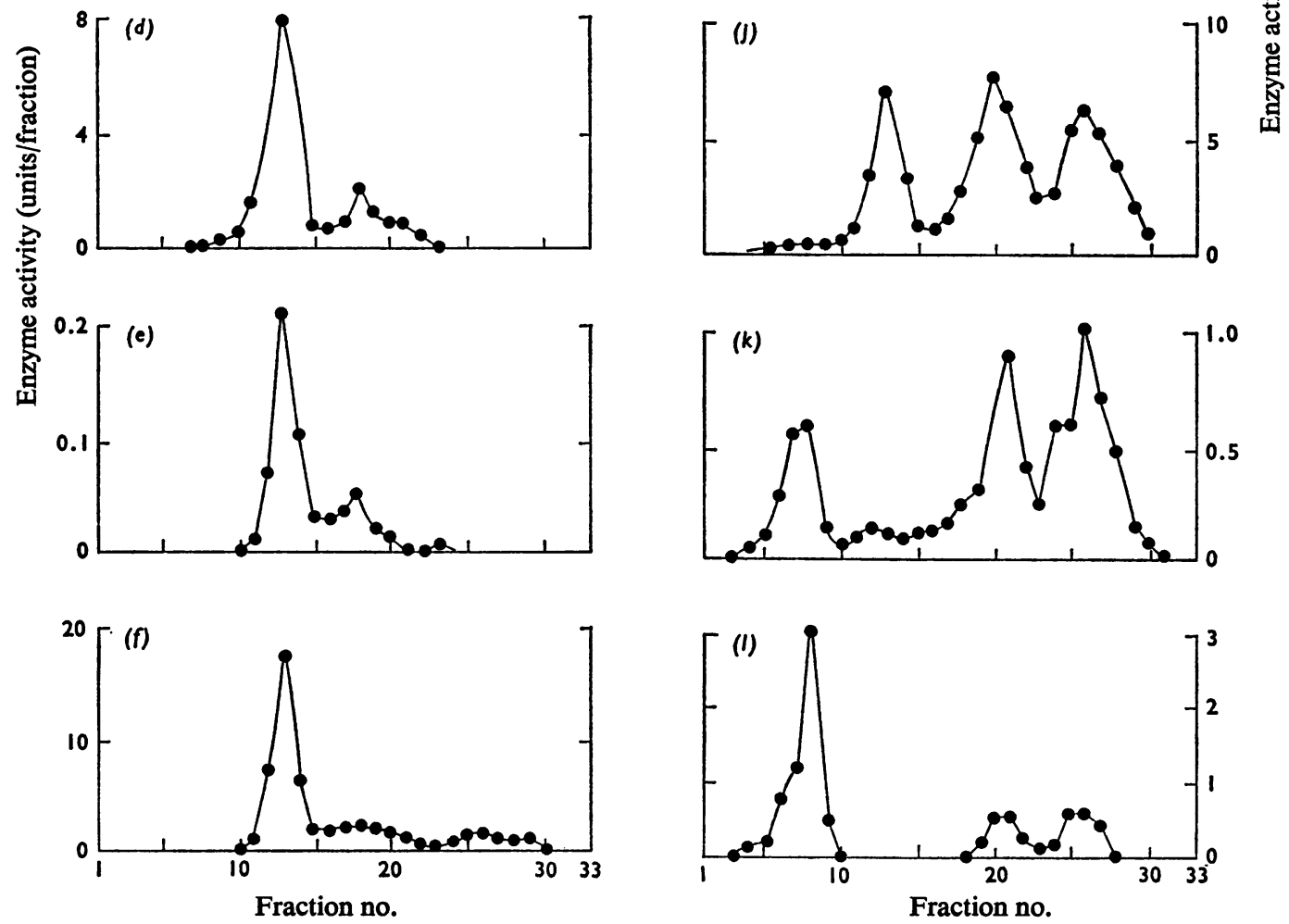
vesicles, portions of capillary endothelium and, very rarely, a brush-border clump. Fraction 26 contained mitochondria, lysosomes, vesicles, plasma membrane, capillary endothelium and some intact cells (Plate $2 b$ ).

From morphological evidence, fractions 12,13 and 14 therefore constitute a highly purified preparation of brush border. The yield of brush border obtained from eight rabbit kidneys was usually in the range $25-50 \mathrm{mg}$ of protein. The resolution of brush border from other particulate elements was dependent on the ionic composition of the medium. Omission of Tris and $\mathrm{MgCl}_{2}$ from the sucrose solutions caused an aggregation of brush borders with lysosomes, as a result of which most of the brush-border fragments penetrated into the denser layers of the gradient. $\mathrm{NaHCO}_{3}(5 \mathrm{mM})$ was almost as effective as Tris$\mathrm{MgCl}_{2}$ in preventing aggregation, but $\mathrm{CaCl}_{2}$, EDTA and dithiothreitol were ineffective.

\section{Enzyme activities identified in the brush border}

Table 2 summarizes the measurements of enzyme activities in the brush-border preparation and compares these values with those in the cortical homogenate. The enzymes fall into three groups. First there is a group of enzymes that were enriched 15-25-fold in the brush-border fraction. This includes the seven enzymes, shown in Fig. 1, that were observed to be predominately localized in peak 13 (the fraction containing most of the brush border). These are alkaline phosphatase, aminopeptidase A, aminopeptidase $M$, neutral peptidase, $\gamma$-glutamyl transpeptidase, maltase and trehalase. In addition, a comparable enrichment was found for 5'-nucleotidase. This group of enzyme activities may be presumed to be wholly or predominantly located in the brush border.

A second category, namely $\left(\mathrm{Na}^{+}+\mathrm{K}^{+}\right)$-activated ATPase and $\mathrm{Mg}^{2+}$-ATPase activities, were also enriched (4- or 5-fold), but to a significantly lesser degree than the first group. The remaining enzyme activities showed either insignificant enrichment, e.g. glucose 6-phosphatase and acid phosphatase (each 1.4-fold), or were impoverished in the brush-border fraction (enrichment factors less than 1.0); this group included lysosomal and mitochondrial marker enzymes and arylesterases. The low activity of lysosomal and mitochondrial enzymes supports the morpho- logical evidence of homogeneity of the brush-border preparation.

\section{Release of enzymes by treatment of kidney brush border with papain}

Some, but not all, of the brush-border enzymes were released by papain (Fig. 2). Aminopeptidase $M$ was rapidly solubilized $(70 \%$ in the first $10 \mathrm{~min}$ and reaching about $90 \%$ in $30 \mathrm{~min}$ ). Another group of enzymes was released at a much slower rate, reaching $40-50 \%$ in $30 \mathrm{~min}$. This group comprised aminopeptidase A, $\gamma$-glutamyl transpeptidase and maltase. The remaining brush-border enzymes were not solubilized by papain during the course of a $30 \mathrm{~min}$ incubation. This group comprised alkaline phosphatase, $\left(\mathrm{Na}^{+}+\mathrm{K}^{+}\right)$-activated ATPase, $\mathrm{Mg}^{2+}$-ATPase, trehalase and the neutral peptidase. This clear-cut difference in the release of aminopeptidase $M$ and the neutral peptidase serves to distinguish these two peptidases.

No significant loss of enzyme activity resulted from papain treatment. The total activity, i.e. pellet plus supernatant, for each of the enzymes was between 90 and $100 \%$. The controls, in which papain had been inactivated with iodoacetate, released no more than $2 \%$ of any enzyme in $30 \mathrm{~min}$.

\section{Separate identities of the brush-border enzymes}

The group of seven hydrolases that are substantially enriched in the brush-border preparation comprise phosphatases, disaccharidases and peptidases. Since some of these enzymes are known to exhibit a broad substrate specificity, it is important to establish the separate identities of these hydrolases.

Phosphatases in the brush-border preparations. The presence of a highly active, non-specific phosphatase (alkaline phosphatase) in the brush border complicates the identification of other, specific, phosphatases. Alkaline phosphatase, assayed with $p$ nitrophenyl phosphate as substrate, is maximally active at $\mathrm{pH} 10$. The hydrolysis of AMP, glucose 6-phosphate and ATP was in each case also maximal at alkaline $\mathrm{pH}$ values (Fig. 3). The specific phosphatases for these three substrates normally exhibit pH optima near neutrality. No additional maxima were observed in the curves obtained with the brushborder fraction, although the peaks are broader,

\section{Fig. 1. Fractionation of kidney cortex by centrifugation in a B XIV zonal rotor}

For details see the Methods section. The volume of fractions is $10 \mathrm{ml}$. Enzyme activities are expressed as units/fraction. (a) Protein (mg/fraction); (b) sucrose (\%,w/v); (c) aminopeptidase $\mathbf{M} ;(d)$ aminopeptidase A; (e) neutral peptidase; $(f) \gamma$-glutamyl transpeptidase; $(g)$ alkaline phosphatase; $(h)$ maltase; $(i)$ trehalase; (j) ATPase; $(k)$ rhodanese; $(l)$ cathepsin C. 


\section{Table 2. Enzyme activities in kidney cortex and brush-border fraction}

For details see the Methods section. Specific activities are means \pm S.E.M. with the numbers of preparations shown in parentheses. Relative specific activity (enrichment) is calculated as the ratio of the mean specific activities of the brush border to that of the cortex homogenate.

$\begin{array}{lcccc}\text { Enzyme } & \begin{array}{c}10^{3} \times \text { Sp. activity of } \\ \text { cortex homogenate }\end{array} & \begin{array}{c}10^{3} \times \text { Sp. activity of } \\ \text { brush-border fraction }\end{array} & \begin{array}{c}\text { Relative specific } \\ \text { activity } \\ \text { (enrichment) }\end{array} & \begin{array}{c}\text { Yield } \\ (\%)\end{array} \\ \text { Alkaline phosphatase } & 183 \pm 16(20) & 2755 \pm 372(12) & 15 & 8.5 \\ \text { Aminopeptidase M (leucine } & 125 \pm 8(17) & 3092 \pm 207(11) & 25 & 14.2 \\ \quad \text { 2-naphthylamide) } & 245 \pm 18(12) & 4581 \pm 457(8) & 19 & 10.8 \\ \begin{array}{l}\text { Aminopeptidase M (alanine } \\ \text { 2-naphthylamide) }\end{array} & 80 \pm 6(12) & 1914 \pm 244(8) & 24 & 13.6 \\ \text { Aminopeptidase M (arginine } & & & & \\ \text { 2-naphthylamide) } & 40 \pm 4(11) & 787 \pm 110(6) & 20 & 11.4 \\ \text { Aminopeptidase A } & 1.7 \pm 0.1(20) & 31 \pm 4(9) & 18 & 10.2 \\ \text { Neutral peptidase } & 105 \pm 10(10) & 1867 \pm 249(9) & 18 & 10.2 \\ \gamma \text {-Glutamyl transpeptidase } & 42 \pm 4(17) & 944 \pm 70(9) & 22 & 12.5 \\ \text { Maltase } & 77 \pm 15(16) & 1170 \pm 186(7) & 15 & 8.5 \\ \text { Trehalase } & 13 \pm 3(15) & 220 \pm 20(8) & 17 & 9.7 \\ \text { 5'-Nucleotidase } & 40 \pm 4(8) & 168 \pm 24(6) & 4 & 2.4 \\ \text { (Na+ +K+)-ATPase } & 136 \pm 9(8) & 752 \pm 32(7) & 5.5 & 3.1 \\ \text { Mg't+-ATPase } & 29 \pm 6(6) & 47 \pm 6(4) & 1.6 & 0.9 \\ \text { Glucose 6-phosphatase } & 3.8 \pm 0.3(14) & 5.9 \pm 0.2(2) & 1.6 & 0.9 \\ \text { Acid phosphatase } & 4.2 \pm 0.4(3) & 0.03(3) & 0.01 & 0.005 \\ \text { Cathepsin C } & 0.23(1) & 0.07(1) & 0.3 & 0.17 \\ \text { Cathepsin D } & 1.4 \pm 0.3(10) & 0.3 \pm 0.07(3) & 0.2 & 0.11 \\ \text { Acid peptidase } & 0.027(1) & 0.02 \pm 0.007(3) & 0.8 & 0.45 \\ \beta \text {-Glucuronidase } & 205 \pm 25(6) & 39 \pm 7(6) & 0.2 & 0.11 \\ \text { Rhodanese } & 1655 \pm 177(2) & 360 \pm 69(4) & 0.2 & 0.11 \\ \text { Esterase (1-naphthyl acetate) } & 245(1) & 85 \pm 7(3) & 0.3 & 0.17 \\ \text { Esterase (2-naphthyl acetate) } & 146 \pm 16(10) & 0.83 \pm 0.09(10) & - & 0.57 \pm 0.06 \\ \text { Protein (mg/g of cortex) } & & & & \end{array}$

especially that for the hydrolysis of ATP, in comparison with that of $p$-nitrophenyl phosphate.

EDTA is a powerful inhibitor of alkaline phosphatase, but has no effect on glucose 6-phosphatase (Nordlie \& Lygre, 1966). Fig. 4 shows that low concentrations of EDTA fully inhibit the hydrolysis of $p$-nitrophenyl phosphate at alkaline and neutral $\mathrm{pH}$ values. The hydrolysis of glucose 6-phosphate and AMP are each $70 \%$ inhibited, whereas the effect of EDTA on ATPase activity is biphasic (activation at low concentrations and weak inhibition at higher concentrations). We may conclude that not more than $30 \%$ of the glucose 6-phosphatase activity can be attributed to the specific enzyme. On the other hand most of the ATPase activity must be due to the action of enzymes other than alkaline phosphatase. This conclusion is supported by the effect of phenylalanine, which completely inhibited the hydrolysis of $p$-nitrophenyl phosphate at $\mathrm{pH} 7.5$, but had no significant effect on either total ATPase or $\left(\mathrm{Na}^{+}+\mathrm{K}^{+}\right)$-activated ATPase activity (Fig. 5). The pH-activity curve for the hydrolysis of ATP (Fig. 3) shows that the rate at $\mathrm{pH} 7.5$ is $83 \%$ of that at $\mathrm{pH} 10$. In this respect, too, it is clearly different from alkaline phosphatase.

The significance of the $5^{\prime}$-nucleotidase activity is more difficult to assess. Alkaline phosphatases purified from human liver, intestine or placenta, hydrolyse AMP at a rate comparable with that for $p$-nitrophenyl phosphate (Eaton \& Moss, 1967; Harkness, 1968). The pH-activity curve for the hydrolysis of $p$-nitrophenyl phosphate by kidney brush border (Fig. 3) shows that the rate at $\mathrm{pH} 7.5$ is about one-tenth of that at $\mathrm{pH} 10$. If the specificity of the rabbit kidney alkaline phosphatase is similar to that of the purified human enzymes, then the specific activity of alkaline phosphatase in the brush border at $\mathrm{pH} 10.0$ $(2.75 \mu \mathrm{mol} / \mathrm{min}$ per $\mathrm{mg}$; see Table 2$)$ is high enough to account for 5 -nucleotidase activity (specific activity $0.22 \mu \mathrm{mol} / \mathrm{min}$ per $\mathrm{mg}$ ) at $\mathrm{pH} 7.5$. As noted above, approx. $30 \%$ of the hydrolysis of AMP was unaffected by EDTA, and might therefore be attributed to an enzyme other than alkaline phosphatase. 


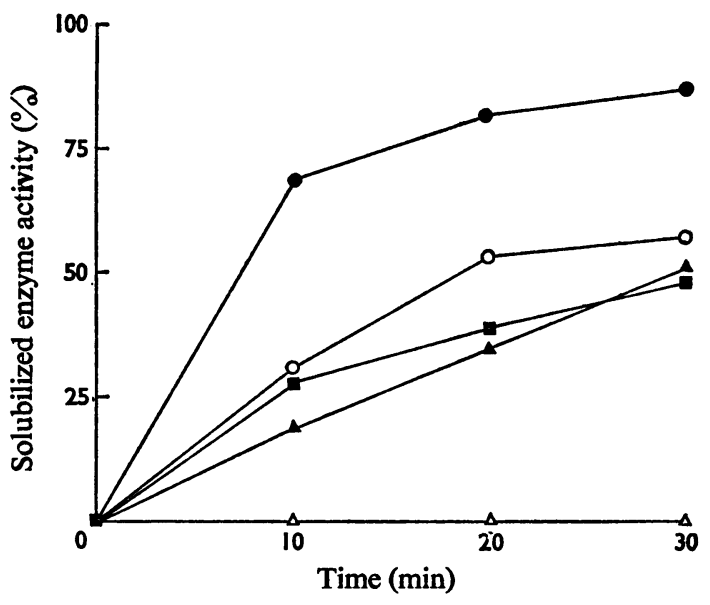

Fig. 2. Release of brush-border enzymes during incubation with papain

For details see the Methods section. Solubility is expressed as the percentage of the activity recovered in the supernatant obtained after centrifugation at $105000 \mathrm{~g}$ for $60 \mathrm{~min}$ compared with that recovered in the pellet plus supernatant fractions. $\bullet$, Aminopeptidase $M$ assayed with three substrates, leucine 2naphthylamide, alanine 2-naphthylamide and arginine 2-naphthylamide; $O, \gamma$-glutamyl transpeptidase; $\boldsymbol{\square}$, maltase; $\Lambda$, aminopeptidase A. Some brush-border enzymes were not released by papain; they were ATPases, alkaline phosphatase, neutral peptidase and trehalase, all shown as $\Delta$. Since papain also hydrolysed iodoinsulin B chain, the neutral peptidase assay was modified by the addition of sufficient iodoacetate to inactivate papain without affecting the neutral peptidase.

Phenylalanine ( $50 \mathrm{~mm}$ ) fully inhibited the hydrolysis of either AMP or $p$-nitrophenyl phosphate by the brush border (Fig. 5). It did not therefore discriminate between the EDTA-insensitive component and the remainder of the 5'-nucleotidase activity. These results do not permit a specific 5 '-nucleotidase to be clearly differentiated from the non-specific phosphatase present in the brush border. Other experiments show that the hydrolysis of the varizus phosphomonoesters at neutral $\mathrm{pH}$ could not be attributed to the action of acid phosphatase arising from any contamination of the brush-border preparations by lysosomes. KF, which is a powerful specific inhibitor of acid phosphatase, completely inhibited the enzyme in a rabbit kidney lysosomal preparation at a concentration of $2 \mathrm{~mm}$. Addition of 1-10mM-KF had no effect on the hydrolysis of

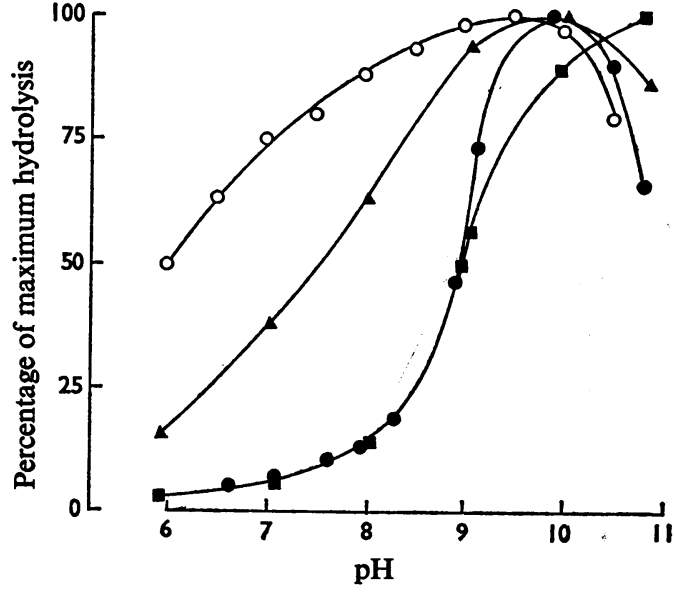

Fig. 3. pH-activity curves of phosphatases in brush border

For details see the Methods section. Substrates: 0 , ATP (5mM); $\wedge$, glucose 6-phosphate (27 mM); $\bullet$, p-nitrophenyl phosphate (5mM);, AMP (15 mM). Buffers $(0.1 \mathrm{M})$ : $\mathrm{pH} 4-5.5$, acetic acid-sodium acetate; pH6-7.5, piperazine- $N N^{\prime}$-bis-(2-ethanesulphonic acid)-NaOH; pH7-9, Tris-HCl; pH8-9, glycylglycine- $\mathrm{NaOH}$; pH 8.5-10.9, glycine- $\mathrm{NaOH}$.

AMP, ATP or p-nitrophenyl phosphate by brushborder preparations at $\mathrm{pH} 7.5$.

Disaccharidase activity in the purified brush-border preparation. In agreement with the report by Berger \& Sacktor (1970), we also observed no measurable hydrolysis of sucrose, lactose or cellobiose by preparations of rabbit kidney brush borders. Maltase and trehalase were identified and these activities were enriched 22- and 15-fold respectively in the brush border. The hydrolysis of these substrates was shown to be due to distinct enzymes by heat treatment of a brush-border preparation. Trehalase activity was unaffected after $30 \mathrm{~min}$ at $60^{\circ} \mathrm{C}$, whereas over $90 \%$ of the maltase activity was destroyed by this treatment.

Peptidase activity of the purified brush-border preparation. Aminopeptidase $\mathbf{M}$ is an enzyme of broad specificity capable of hydrolysing a wide range of amino acid 2-naphthylamides and aminoacyl $p$ nitroanilides, as well as simple peptides of various chain lengths (Pfleiderer et al., 1964). Table 3 shows the rates of hydrolysis for a range of substrates incubated with purified rabbit kidney aminopeptidase M, cortex homogenate and brush border. The specific activities for the hydrolysis of three $\alpha$-amino acid 2-naphthylamides by brush border were 4.1-4.8\% of the values for the purified enzyme. From these 


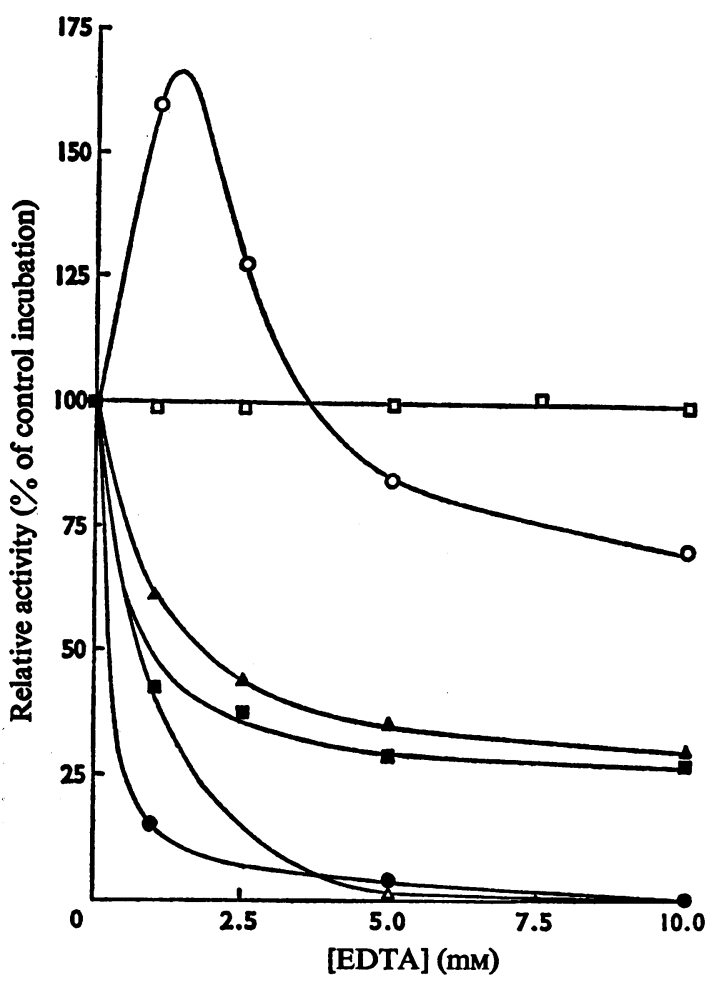

Fig. 4. Effect of EDTA on phosphatases in brush border

For details see the Methods section. Substrates: $\bullet$, p-nitrophenyl phosphate, $\mathrm{pH} 10 ; \square, p$-nitrophenyl phosphate, pH5; $\Delta$, p-nitrophenyl phosphate, pH 7.5; $\Delta$, glucose 6-phosphate, pH6.5; 口, AMP, pH 7.4; $\circ$, ATP, pH 7.5. Relative activity is expressed as the percentage of that of the control incubation, without EDTA.

values one may conclude that aminopeptidase $\mathbf{M}$ constitutes $4-5 \%$ of the protein of the brush border. If an additional peptidase contributes significantly to the hydrolysis of a peptide by the brush-border preparatlon the specific activity should exceed $5 \%$ of the value obtained with pure aminopeptidase $\mathbf{M}$. This provides one criterion by which the presence of other peptidases may be judged. Of the unsubstituted peptides, the hydrolysis of glycyl-leucine and glycylglutamic acid was marginally above this value, and that of leucylglycylglycine was substantially higher. Although this suggests the presence of additional peptidases in the brush-border fraction, it should be noted that in none of these instances was there any enrichment of the activities in the fraction compared with the cortex homogenate. This ex-

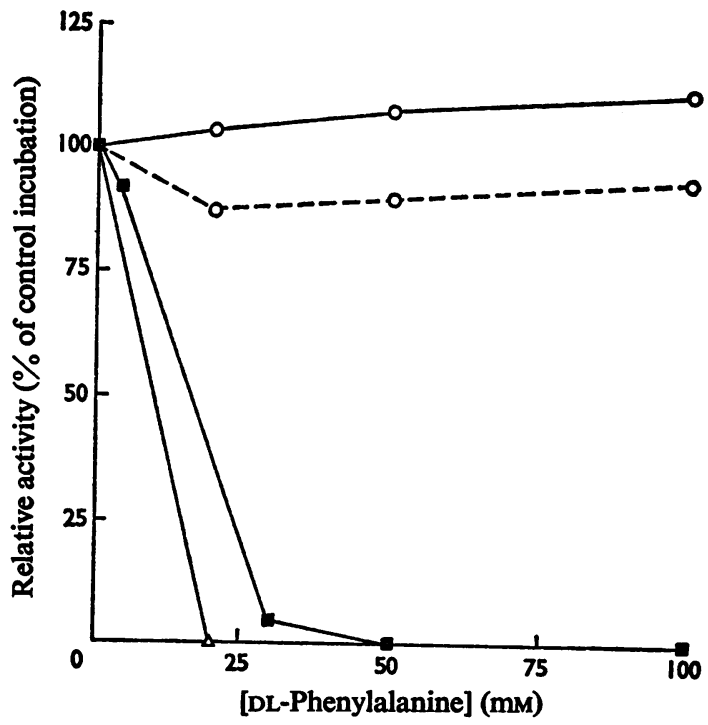

Fig. 5. Effect of phenylalanine on phosphatases in brush border

For details see the Methods section. Substrates: $\bigcirc-0$, ATP (total ATPase activity, pH7.5); $0---0$, ATP $\left[\left(\mathrm{Na}^{+}+\mathrm{K}^{+}\right)\right.$-activated ATPase activity, pH7.5]; 口, AMP, pH 7.4; $\Delta$, p-nitrophenyl phosphate, pH7.4. Relative activity is expressed as the percentage of that of the control incubation, without phenylalanine.

cludes the possibility that the hydrolysis of these peptides was mainly attributable to aminopeptidase $\mathrm{M}$ or to another brush-border peptidase. Kirschke \& Hanson (1969) have reported a microsomal tripeptidase in rat kidney that hydrolysed leucylglycylglycine and glycylglycylglycine at comparable rates. In the brush border the rates differed by a factor of 20 (Table 3), hence the hydrolysis of leucylglycylglycine is not due to the activity of this microsomal tripeptidase.

No imido- or imino-dipeptidase activity was demonstrable in the brush-border preparation. Very low rates of hydrolysis were found for several carboxypeptidase substrates (hippurylarginine, hippurylphenylalanine, benzyloxycarbonylglycylphenylalanine, benzyloxycarbonylpropylalanine); again, none showed any enrichment in the brush border. The lastnamed substrate is specific for carboxypeptidase $P$, a microsomal peptidase purified by Dehm \& Nordwig (1970b). Dehm \& Nordwig (1970a) described another kidney aminopeptidase, which attacks L-aminoacylprolylpeptides. Since this enzyme also attacked the dipeptide glycylproline at a substantial rate, the 
Table 3. Hydrolysis of peptide substrates by kidney cortex, brush border and purified aminopeptidase $M$

The substrates were present at a concentration of $0.125 \mathrm{mM}$, except for the 2-naphthylamides ( $0.2 \mathrm{~mm})$ and iodoinsulin B chain $(5.7 \mu \mathrm{M})$.

Sp. activity ( $\mu \mathrm{mol}$ hydrolysed/min per mg of protein)

Substrate

Leu 2-naphthylamide

Ala 2-naphthylamide

Arg 2-naphthylamide

$\alpha$-Glu acid 2-naphthylamide

$\gamma$-Glu acid 2-naphthylamide

$\boldsymbol{\gamma}$-Glu acid 2-naphthylamide (+Gly-Gly)

Gly-Gly

Gly-Leu

Gly-Glu

Gly-Pro

Leu-Gly

Pro-Gly

Ala-Trp

Gly-Gly-Gly

Gly-Gly-Gly-Gly-Gly

Leu-Gly-Gly

Gly-Gly-Phe

Hippuryl-Arg

Hippuryl-Phe

Cbz-Gly-Phe

Cbz-Pro-Ala

Iodoinsulin B chain

\begin{tabular}{|c|c|c|c|}
\hline Cortex (homogenate) & $\begin{array}{l}\text { Brush border } \\
\text { (A) }\end{array}$ & $\begin{array}{c}\text { Aminopeptidase } \mathbf{M} \\
\text { (B) }\end{array}$ & $100 \times$ ratio $(\mathrm{A} / \mathrm{B})$ \\
\hline $\begin{array}{l}0.125 \\
0.245 \\
0.080 \\
0.040\end{array}$ & $\begin{array}{l}3.10 \\
4.58 \\
1.91 \\
0.79\end{array}$ & $\begin{array}{c}67 \\
95 \\
47 \\
0.60\end{array}$ & $\begin{array}{c}4.6 \\
4.8 \\
4.1 \\
76\end{array}$ \\
\hline 0.031 & 0.66 & 0.13 & 508 \\
\hline 0.105 & 1.87 & 0.32 & 584 \\
\hline - & 0 & $\mathbf{0}$ & - \\
\hline 2.1 & 0.04 & 0.45 & 9 \\
\hline 一 & 0.04 & 0.39 & 10 \\
\hline 0.3 & $\mathbf{0}$ & $\mathbf{0}$ & - \\
\hline - & 0.15 & 3.8 & 4 \\
\hline 0.6 & 0 & 0 & - \\
\hline - & 0.16 & 9.0 & 2 \\
\hline 0.33 & 0.02 & 0.35 & 6 \\
\hline 0.2 & 0.02 & 0.44 & 5 \\
\hline 2.5 & 0.44 & 1.75 & 25 \\
\hline - & 0.26 & - & - \\
\hline - & $<0.0025$ & 0 & - \\
\hline 0.0025 & 0.0006 & 0 & - \\
\hline 0.0025 & 0.001 & $\mathbf{0}$ & - \\
\hline 0.006 & 0.004 & - & - \\
\hline 0.0017 & 0.031 & 0.043 & 72 \\
\hline
\end{tabular}

absence of any hydrolysis of this substrate by the brush border indicates that this microsomal enzyme is located in structures other than the brush border.

The specific activities observed for iodoinsulin B chain, the substrate employed in the assay of the neutral peptidase, establish that this substrate is hydrolysed in the brush border by an enzyme additional to aminopeptidase $M$. Since aminopeptidase $\mathrm{M}$ constitutes $5 \%$ of the brush-border protein one may calculate that its contribution to the hydrolysis of iodoinsulin B chain by the brush border is no more than about $7 \%$ of the total rate. Indeed, papain treatment of brush border released no apparent neutral peptidase activity into the supernatant, although most of the aminopeptidase $M$ was solubilized. Two other peptidases ( $\gamma$-glutamyl transpeptidase and aminopeptidase A) were partially solubilized by papain. Although purified aminopeptidase $\mathbf{M}$ exhibited some activity towards the substrates for these enzymes, the relatively high activities present in brush border preclude any significant contribution by aminopeptidase $M$. The separate identities of the peptidases was confirmed by investigation of certain properties of these enzymes.

Glenner et al. (1962) have shown that a partially purified preparation of aminopeptidase $A$ from rat kidney was $\mathrm{Ca}^{2+}$-activated. The activity in rabbit brush border shows a comparable (3-fold) stimulation by $\mathrm{Ca}^{2+}$ (Fig. 6). The other brush-border peptidases were insensitive to $\mathrm{Ca}^{2+} \cdot \gamma$-Glutamyl transpeptidase, purified from ox kidney, is inhibited competitively by L-serine in the presence of borate (Szewczuk \& Connell, 1965). The brush-border activity (Fig. 7) was similarly inhibited by concentrations of serine that had little effect on aminopeptidases A or M, or the neutral peptidase.

The three peptidases that were released by papain treatment of the brush border could be resolved by electrophoresis in polyacrylamide gels (Fig. 8). In a $5 \%$ polyacrylamide gel the enzymes migrated in the order aminopeptidase $\mathbf{M}$, aminopeptidase $\mathbf{A}, \gamma$ glutamyl transpeptidase.

Effect of aminopeptidase $M$ antiserum on the peptidase activities of the brush border. The antiserum, raised in guinea pigs, inhibited the activity of 


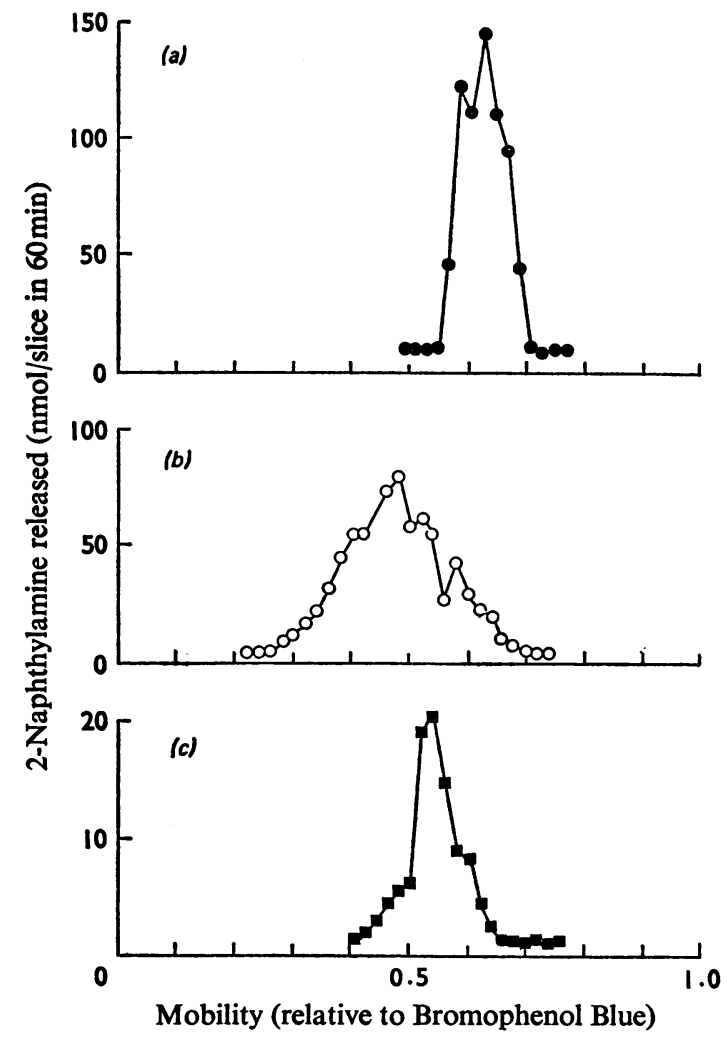

Fig. 6. Electrophoresis on polyacrylamide gels of the soluble fraction after papain treatment of brush border

Brush border was incubated with papain for $60 \mathrm{~min}$ and portions of the $105000 \mathrm{~g}$ supernatant were applied to $5 \%$ polyacrylamide gels (Davis, 1964). Similarly treated gels were frozen, $1 \mathrm{~mm}$ slices were cut and assayed for enzymic activity by incubating for $60 \mathrm{~min}$ with the following substrates: $(a)$ leucine 2-naphthylamide; (b) $\gamma$-glutamic acid 2-naphthylamide (glycylglycine was also added in this incubation); (c) $\alpha$ glutamic acid 2-naphthylamide.

the purified aminopeptidase M (Fig. 9). Similar inhibition was observed with brush border; the inhibition curves for aminopeptidase $M$ were essentially the same for three different substrates, leucine 2-naphthylamide, alanine 2-naphthylamide and arginine 2-naphthylamide. This is to be expected, since this peptidase readily attacks all three substrates (Table 3). However, neither $\gamma$-glutamyl transpeptidase nor the neutral peptidase was inhibited by the antiserum. Aminopeptidase A was weakly inhibited by the antiserum; at the highest concentration of serum only about $50 \%$ inhibition was observed. This effect is not due to the ability of amino-

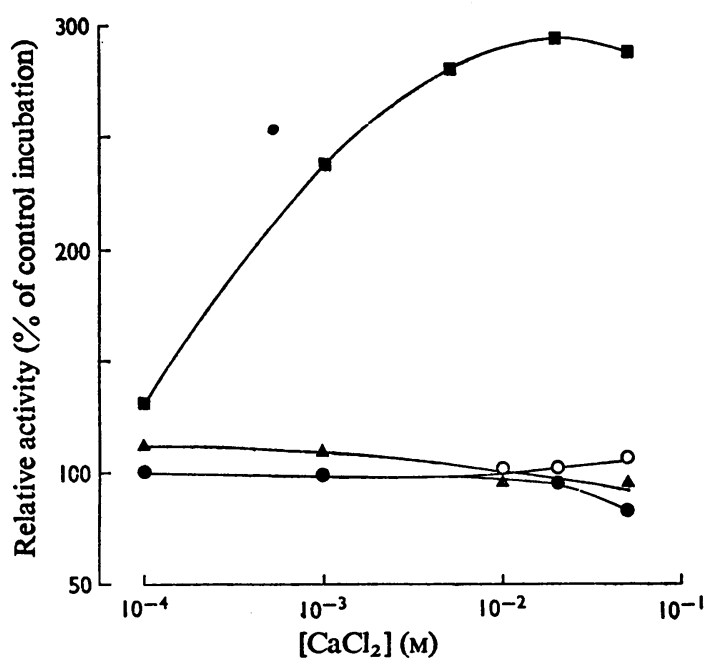

Fig. 7. Effect of $\mathrm{Ca}^{2+}$ on peptidases in brush border

For details see the Methods section. A brush-border preparation was preincubated for $30 \mathrm{~min}$ at $37^{\circ} \mathrm{C}$. Samples were assayed with the following substrates: -, leucine 2-naphthylamide; $\boldsymbol{\omega}, \alpha$-glutamic acid 2naphthylamide. $\bigcirc, \gamma$-glutamic acid 2-naphthylamide; $\Delta$, iodoinsulin B chain. Concentrations shown are those in the preincubation mixture. Relative activity is expressed as the percentage of that of the control incubation, without $\mathrm{Ca}^{2+}$.

peptidase $M$ to hydrolyse $\alpha$-glutamic acid 2-naphthylamide, since we calculate that this enzyme accounts for no more than $4 \%$ of the aminopeptidaseA activity of brush border. The shape of the titration curve for aminopeptidase $A$ in the brush border may therefore indicate either some antigenic crossreactivity of aminopeptidases $A$ and $M$ or that the binding of the antibody to aminopeptidase $M$ on the microvillus membrane may sterically hinder the access of $\alpha$-glutamic acid 2-naphthylamide to the catalytic site of aminopeptidase $\mathbf{A}$.

\section{Discussion}

The method employed for the preparation of kidney brush border was based on that of Kinne \& KinneSaffran (1969), but involved several modifications of their procedure. A tissue press was employed to disintegrate the kidney cortex. This gave a consistent and predictable yield of brush-border fragments in the initial low-speed pellet. The composition of the medium was simplified to avoid interference with certain of the enzyme assays. A B XIV zonal rotor and a modified density gradient were also introduced into the final preparative steps. Quirk \& Robinson 


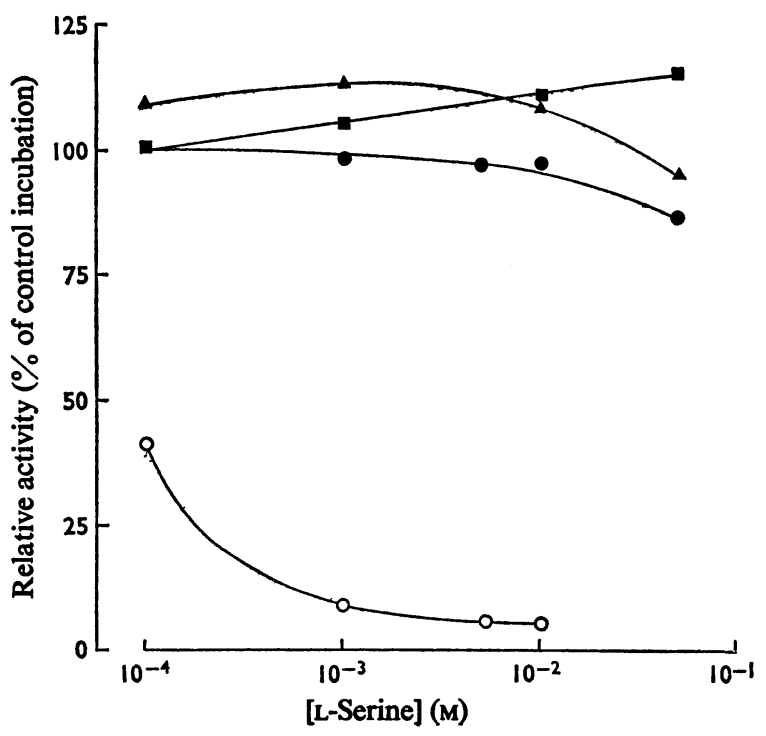

Fig. 8. Effect of L-serine and borate buffer on peptidases in brush border

For details see the Methods section. Substrates: $\bullet$, leucine 2-naphthylamide; $\square$, $\alpha$-glutamic acid 2naphthylamide; $O, \gamma$-glutamic acid 2-naphthylamide; $\Delta$, iodoinsulin B chain. Assay buffers, $100 \mathrm{~mm}$-sodium borate-boric acid at the $\mathrm{pH}$ values appropriate to each enzyme. Relative activity is expressed as the percentage of that of the control incubation, without serine.

(1972) have also employed a B XIV zonal rotor in a procedure that differs from ours and is in some respects analogous to that of Thuneberg \& Rostgaard (1968) in that it depends on a rate-zonal step placed early in the scheme followed by a series of differential centrifugation steps designed to remove contaminants. Our method involves fewer operations than that of Quirk \& Robinson (1972), six differential steps compared with 12 or 13 . We were able to process $50 \mathrm{~g}$ of kidney cortex in each preparation, compared with their $10-20 \mathrm{~g}$, and the yield of brush border was proportionately increased. Contamination by other organelles (as judged by marker enzymes) was very low in both preparations, though ours may (on the basis of glucose 6-phosphatase activity) have contained some fragments of endoplasmic reticulum.

In this study, seven enzymes were proved to be predominantly, if not exclusively, located in the brush border. In each instance, the enzyme was enriched (compared with the cortical homogenate) 15-25-fold. Other workers have reported comparable enrichment values for some, but not all, of these enzymes

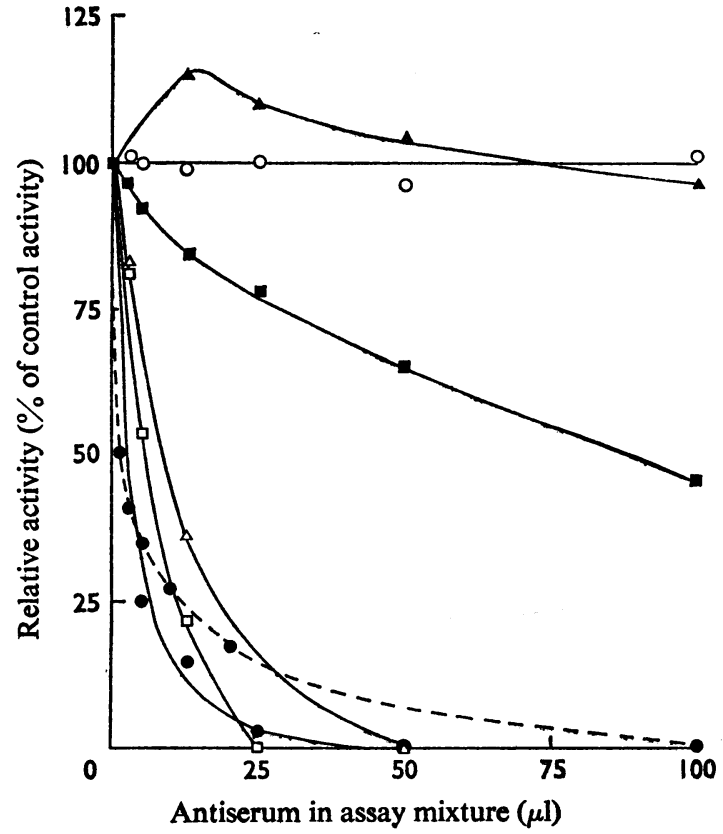

Fig. 9. Effect of guinea-pig antiserum (raised to rabbit aminopeptidase $M$ ) on peptidases in rabbit brush border

For details see the Methods section. Substrates: $\bullet$, leucine 2-naphthylamide; $\Delta$, arginine 2-naphthylamide; $\square$, alanine 2-naphthylamide; $\boldsymbol{\square}, \alpha$-glutamic acid 2-naphthylamide; $\circ, \gamma$-glutamic acid 2-naphthylamide; $\Lambda$, iodoinsulin $\mathbf{B}$ chain. __, Brush border; - ---, pure aminopeptidase M. Each assay mixture contained $5 \mu \mathrm{g}$ of brush-border protein or $0.2 \mu \mathrm{g}$ of aminopeptidase $\mathrm{M}$. The antiserum possessed some arylamidase activity, hence the appropriate corrections were made to the brush-border activities. Relative activity is expressed as the percentage of the control incubation, without antiserum

(Table 4). Some anomalies are apparent which make it difficult to define, at present, the ideal marker enzyme for the renal brush border. Although alkaline phosphatase was greatly enriched in five preparations, Berger \& Sacktor (1970) achieved only 4.5-fold enrichment. Aminopeptidase $M$ was markedly enriched in two preparations of rabbit kidney brush border but only poorly enriched in two preparations from rat kidney. Glossmann \& Neville (1972) found that $\gamma$-glutamyl transpeptidase was only weakly enriched. This contrasts with the high enrichment in our preparations. Other workers have not reported on the localization of aminopeptidase A nor on an enzyme comparable with the neutral peptidase. There seems to be no disagreement with respect to the two disaccharidases, maltase and trehalase. Perhaps these 
Table 4. Enrichment values reported by various authors for enzyme in kidney brush border

Enrichments are expressed as the ratio of the specific activity in the brush border to that of the kidney cortex. Authors: KK, Kinne \& Kinne-Saffran (1969); WN, Wilfong \& Neville (1970); GN, Glossmann \& Neville (1972); BS, Berger \& Sacktor (1970); QR, Quirk \& Robinson (1972); GK, this paper.

\begin{tabular}{|c|c|c|c|c|c|c|}
\hline $\begin{array}{ll}\text { Authors } & \ldots \\
\text { Animals } & \ldots\end{array}$ & $\begin{array}{l}\text { KK } \\
\text { Rat }\end{array}$ & $\begin{array}{l}\text { WN } \\
\text { Rat }\end{array}$ & $\begin{array}{l}\text { GN } \\
\text { Rat }\end{array}$ & $\begin{array}{c}\text { BS } \\
\text { Rabbit }\end{array}$ & $\begin{array}{c}\text { QR } \\
\text { Rabbit }\end{array}$ & $\underset{\text { Rabbit }}{\text { GK }}$ \\
\hline Alkaline phosphatase & 12 & 16 & 16 & 4.5 & 19 & 15 \\
\hline $5^{\prime}$-Nucleotidase & - & - & 17 & - & - & 17 \\
\hline $\mathrm{Mg}^{2+}-$ ATPase & 1.4 & - & - & - & 3.7 & 5.5 \\
\hline$\left(\mathrm{Na}^{+}+\mathrm{K}^{+}\right)$-activated ATPase & 4.4 & - & - & - & 5.0 & 4.0 \\
\hline Total ATPase & 2.4 & 1.9 & - & 2.8 & - & 4.8 \\
\hline Maltase & - & - & 17 & 14 & 16 & 22 \\
\hline Trehalase & - & - & - & 12 & 14 & 15 \\
\hline Aminopeptidase A & - & - & - & - & - & 20 \\
\hline Aminopeptidase $\mathbf{M}$ & 3.5 & - & 4.0 & - & 15 & 25 \\
\hline$\gamma$-Glutamyl transpeptidase & - & - & 5.0 & - & - & 18 \\
\hline Neutral peptidase & - & - & - & - & - & 18 \\
\hline
\end{tabular}

enzymes may prove to be the most reliable brushborder markers.

ATPase activity, whether assayed as total activity or as $\mathrm{Mg}^{2+}$ or $\left(\mathrm{Na}^{+}+\mathrm{K}^{+}\right)$-activated activities, was present in our brush-border fraction, each being enriched by a factor of 4 or 5. Other authors (Kinne \& Kinne-Saffran, 1969; Quirk \& Robinson, 1972) observed enrichments in the range 1.4-5.0 in their preparations. Histochemical methods have shown greater ATPase activity in the basal infoldings of the plasma membrane than in the brush border of the proximal tubule cell (Ishii et al., 1968). However, this technique causes inhibition of $\left(\mathrm{Na}^{+}+\mathrm{K}^{+}\right)$-activated ATPase and hence cannot be used to demonstrate the localization of this component (Jacobsen \& Jorgensen, 1969). Most of the cortical ATPase activity is located in the distal, rather than the proximal, tubule (Schmidt \& Dubach, 1969) and may be a source of contaminating activity in brush-border preparations. Kinne et al. (1971) have achieved an electrophoretic separation of $\left(\mathrm{Na}^{+}+\mathrm{K}^{+}\right)$-activated ATPase from alkaline phosphatase in subcellular fractions of rat kidney cortex. They conclude that $\left(\mathrm{Na}^{+}+\mathrm{K}^{+}\right)$activated ATPase is not a brush-border enzyme. By using a sensitive assay system for ATPases, Schmidt \& Dubach (1971) have shown by microdissection that the basal area fragments of the rat proximal tubule cells contain almost all the $\left(\mathrm{Na}^{+}+\mathrm{K}^{+}\right)$-activated ATPase, but $\mathrm{Mg}^{2+}$-ATPase has the same activity in these and the brush-border fragments. Hence one may conclude that $\left(\mathrm{Na}^{+}+\mathrm{K}^{+}\right)$-activated ATPase activity in the brush-border fraction indicates contamination with portions of the basal plasma membrane (from distal or proximal tubule cells).

Treatment of a microsomal fraction of rabbit kidney with papain had shown that aminopeptidase $M$ but not alkaline phosphatase nor neutral peptidase was released in a soluble form (Kenny et al., 1969). Thomas \& Kinne (1972) confirmed this observation with purified rat kidney brush-border preparations. We have extended the observations to all the brushborder enzymes so far identified. Aminopeptidase $\mathbf{M}$ is unique in its ease of solubilization, perhaps because it is superficially located on the microvillus. But a second group of enzymes (aminopeptidase A, $\gamma$ glutamyl transpeptidase and maltase) were also released, but at a slower rate. This group contrasts with the other brush-border enzymes, which perhaps, being more deeply situated in the microvillus, were not affected by papain.

The brush-border enzymes so far identified are all hydrolases and some, e.g. alkaline phosphatase and aminopeptidase $\mathbf{M}$, are enzymes with a broad substrate specificity. For this reason we considered it essential to demonstrate the separate identities of the phosphatases, disaccharidases and peptidases that have been attributed to the renal brush border. Thus the pH-activity curves, together with the effects of EDTA and phenylalanine, served to establish that the ATPase activities were not due to the action of alkaline phosphatase. On the other hand, we could not demonstrate unequivocally that the hydrolysis of AMP was the result of a specific 5'-nucleotidase. This activity was enriched to the same extent as that reported by Glossmann \& Neville (1972). These authors corrected their results for non-specific phosphate activity and employed several inhibitors (cysteine, dithiothreitol, fluoride, dodecyl sulphate and $\mathrm{NiCl}_{2}$ ), which they observed had different effects on the non-specific and specific enzyme activities. In our brush-border preparation the low rate of hydrolysis of AMP was consistent with the activity of alkaline phosphatase at pH7.5. Although $30 \%$ of the apparent 5'-nucleotidase activity was EDTA-in- 
sensitive, and therefore distinguishable from alkaline phosphatase, we failed to discriminate between the two activities with thiols, fluoride or $\mathrm{NiCl}_{\mathbf{2}}$. Until it is possible to solubilize and resolve the phosphatases of the brush border we prefer to be open-minded about the localization of $5^{\prime}$-nucleotidase.

There is no doubt that maltose and trehalose are hydrolysed by different enzymes in the brush border. These activities were distinguished by the heat-lability of maltase.

The four peptidases form an important group of brush-border enzymes. Three are 'arylamidases' in the sense that they can be conveniently detected by the use of synthetic aromatic derivatives of amino acids, e.g. 2-naphthylamides. The fourth is a neutral peptidase of uncertain specificity which can be detected by a sensitive assay using [ ${ }^{125}$ I] iodoinsulin $B$ chain. Since aminopeptidase $M$ is also capable of hydrolysing insulin B chain it was essential to distinguish these two peptidases. Their properties in a kidney microsomal fraction have been shown to differ conclusively in several respects (Kenny et al., 1968). The evidence is extended in the present paper by the use of a specific antiserum to rabbit aminopeptidase $M$. This serum inhibited the activity not only of purified aminopeptidase $M$ but also that present in brush border, when assayed with leucine 2-naphthylamide, alanine 2-naphthylamide or arginine 2-naphthylamide. It failed to inhibit either the neutral peptidase or $\gamma$-glutamyl transpeptidase and it was only weakly inhibitory towards aminopeptidase $\mathbf{A}$ in the brush border. We conclude that four distinct peptidases are located in the brush border.

We are grateful to the Medical Research Council for a grant in support of this work. We also thank Mrs. Jean Ingram for technical assistance and Mr. A. Cline for his help in preparing the antiserum.

\section{References}

Berger, S. J. \& Sacktor, B. (1970) J. Cell Biol. 47, 637-645 Bergeron, M. \& Morel, F. (1969) Amer. J. Physiol. 216, 1139-1149

Bessey, O. A., Lowry, O. H. \& Brock, M. J. (1946) J. Biol. Chem. 164, 321-329

Binkley, F., Leibach, F. \& King, N. (1968) Arch. Biochem. Biophys. 128, 397-405

Bowen, T. J., Butler, P. J. \& Happold, F. C. (1965) Biochem. J. 97, 651-657

Crestfield, A. M., Moore, S. \& Stein, W. H. (1963) J. Biol. Chem. 238, 622-627

Dahlquist, A. (1964) Anal. Biochem. 7, 18-25

Davis, B. J. (1964) Ann. N.Y. Acad. Sci. 121, 404-427

de Duve, C., Pressman, B. C., Gianetto, R., Wattiaux, R. \& Applemans, F. (1955) Biochem. J. 60, 604-617

Dehm, P. \& Nordwig, A. (1970a) Eur. J. Biochem. 17, 364-371

Dehm, P. \& Nordwig, A. (1970b) Eur. J. Biochem. 17, 372-377
Eaton, R. H. \& Moss, D. W. (1967) Biochem. J. 102, 917-921

Fullarton, J. R. \& Kenny, A. J. (1970) Biochem. J. 116, 147-149

Gianetto, R. \& de Duve, C. (1955) Biochem. J. 59, 433-438

Glenner, G. G., McMillan, P. J. \& Folk, J. E. (1962) Nature (London) 194, 867

Glossmann, H. \& Neville, D. M. (1972) FEBS Lett. 19, 340-344

Glover, J. S., Salter, D. N. \& Shepherd, B. P. (1967) Biochem. J. 103, 120-128

Harkness, D. R. (1968) Arch. Biochem. Biophys. 126, 513523

Ishii, S., Nagai, K., Ikeura, T., Ikeda, T., Shiozaki, Y., Yoshida, H. \& Kuob, K. (1968) Okajimas Folia Anat. Jap. 45, 21-33

Jacobsen, N. \& Jorgensen, P. L. (1969) J. Histochem. Cytochem. 17, 443-453

Jorgensen, P. L. \& Skou, J. C. (1969) Biochem. Biophys. Res. Commun. 37, 39-46

Kenny, A. J., Wong-Leung, Y. L. \& Ingram, J. (1968) Biochem. J. 110, 6P

Kenny, A. J., George, S. G. \& Aparicio, S. G. R. (1969) Biochem. J. 115, 18P

Kinne, R. \& Kinne-Saffran, E. (1969) Pflügers Arch. Gesamte Physiol. 308, 1-15

Kinne, R., Schmitz, J.-E. \& Kinne-Saffran, E. (1971) Pflügers Arch. Gesamte Physiol. 329, 191-206

Kirschke, H. \& Hanson, H. (1969) Hoppe-Seyler's Z. Physiol. Chem. 350, 1437-1448

Loeschke, K. \& Baumann, K. (1969) Pfiügers Arch. Gesamte Physiol. 302, 139-154

Lowry, O. H., Rosebrough, N. T., Farr, A. L. \& Randall, R. J. (1951) J. Biol. Chem. 193, 265-275

Michell, R. H. \& Hawthorne, J. N. (1965) Biochem. Biophys. Res. Commun. 21, 333-338

Miller, F. \& Palade, G. E. (1964) J. Cell Biol. 23, 519-552

Nordlie, R. C. \& Lygre, D. G. (1966) J. Biol. Chem. 241, 3136-3141

Oyama, V. I. \& Eagle, H. (1956) Proc. Soc. Exp. Biol. Med. 91, 305-307

Pfleiderer, G., Celliers, P. G., Stanulovic, M., Wachsmuth, E. D., Determann, H. \& Braunitzer, G. (1964) Biochem. Z. 340, 552-564

Quirk, S. J. \& Robinson, G. B. (1972) Biochem. J. 128, 1319-1328

Sargent, J. R. (1969) Methods in Zone Electrophoresis, 2nd edn., pp. 78-83, BDH Chemicals Ltd., Poole

Schmidt, U. \& Dubach, U. C. (1969) Pflïgers Arch. Gesamte Physiol. 306, 219-226

Schmidt, U. \& Dubach, U. C. (1971) Pfügers Arch. Gesamte Physiol. 330, 265-270

Strauss, W. (1957) J. Biophys. Biochem. Cytol. 3, 10371039

Szewczuk, A. \& Connell, G. E. (1965) Biochim. Biophys. Acta 105, 352-367

Thomas, L. \& Kinne, R. (1972) Biochim. Biophys. Acta 225, 114-125

Thuneberg, L. \& Rostgaard, J. (1968) Exp. Cell Res. 51, 123-140

Wilfong, R. F. \& Neville, D. M. (1970) J. Biol. Chem. 245, 6106-6112

Vol. 134 